\title{
CYTOTOXICITY OF STRAWBERRY EXTRACT ON ORAL CANCER CELL LINE
}

\author{
RAMYA G ${ }^{1}$, VISHNU PRIYA V ${ }^{2 *}$, GAYATHRI R ${ }^{2}$
}

${ }^{1}$ Department of Biochemistry, Saveetha Dental College, Saveetha Institute of Medical and Technical Sciences, Saveetha University, Chennai, Tamil Nadu, India. ${ }^{2}$ Department of Biochemistry, Saveetha Dental College, Saveetha Institute of Medical and Technical Sciences, Saveetha University, Chennai, Tamil Nadu, India. Email: drvishnupriyav@gmail.com

Received: 15 March 2018, Revised and Accepted: 01 June 2018

ABSTRACT

Objective: Berries including strawberry may have beneficial effects against oxidative stress-mediated diseases such as cancer. The purpose of the present study was to investigate the cytotoxic effects of strawberry extract on oral cancer cell line.

Methods: Strawberry methanolic extract (SBE) was prepared, and cytotoxic activity of different concentration of SBE on KB cell lines was determined by (3-[4,5-dimethylthiazol-2-yl]-2,5-diphenyltetrazolium bromide) assay and neutral red dye incorporation test.

Results: Strawberry extract exhibits cytotoxic activity over the oral cancer cell lines. On administration of about $100 \mu \mathrm{g} / \mathrm{ml}$ of strawberry extract, about $50 \%$ of cell viability could be observed and assessed from the cell lines.

Conclusion: Strawberries have a cytotoxic effect on oral cancer cell line due to the presence of anticancer constituents in the berries. These berries can be used as a natural medicine for cancer sufferers.

Keywords: Apoptosis, Berries, Cancer, Cytotoxic effect, (3-[4,5-Dimethylthiazol-2-yl]-2,5-diphenyltetrazolium bromide), Neutral red.

(C) 2018 The Authors. Published by Innovare Academic Sciences Pvt Ltd. This is an open access article under the CC BY license (http://creativecommons. org/licenses/by/4. 0/) DOI: http://dx.doi.org/10.22159/ajpcr.2018.v11i9.25955

\section{INTRODUCTION}

Reactive oxygen species (ROS) are tumorigenic by their ability to increase cell proliferation, survival, and cellular migration. Ethnobotany, the study of traditional human uses of plants, is recognized as an effective way to discover future medicines [1]. Antioxidants have the potential to suppress cancer and to reduce the risk of cancer development by scavenging ROS [2]. Intake of Vitamin E, C, and A has been reported to reduce lung cancer risk because of their roles as regulators of cell differentiation (Vitamin A), antioxidants (Vitamins C and E), and modulators of DNA synthesis, methylation, and repair [3]. Berries are said to be vital sources of natural chemopreventive agents comprising Vitamins A, C, and E, selenium, carotenoids, anthocyanins, flavonols, proanthocyanidins, ellagitannins, and phenolic acids that have anticancer effects [4].

Berry fruits have been widely consumed in our diet and have attracted much attention due to their potential health benefits [5]. Berries contain a diverse range of phytochemicals with properties of antioxidant, anticancer, and anti-inflammatory works [6]. Berries possess many cancer-preventive substances in them including vitamins such as A, C, and E, folic acid, as well as minerals, such as calcium, selenium, and zinc [7]. Berry bioactives are known to have many roles in cancer prevention. Inhibition of the formation of carcinogeninduced DNA adducts, inhibition of carcinogen-induced tumorigenesis in animals, and modulation of signaling pathways involved with cellular proliferation, apoptosis, inflammation, angiogenesis, and cell cycle arrest include in the many roles it plays $[8,9]$.

Cancer till today remains the leading cause of death in both developed and developing countries [10]. Plants have been beacon of therapeutic sources for curing diseases from times immemorial [11]. Strawberry, one of the most commonly berries consumed in the Mediterranean diet, is a rich source of antioxidants and phenolic compounds that exert beneficial effects on human health [12]. However, to date, there is a lack of investigation about its cytotoxic effects $[13,14]$. Berries including strawberry, Korean raspberry, and mulberry are noted to have beneficial effects against diseases such as cancer [15]. Hence, the present study aimed at evaluating the cytotoxic activity of strawberry extract on oral cancer cell line.

\section{METHODS}

\section{Extract preparation}

For the preparation of strawberry methanolic extract (SBE), Indian strawberry fruits were purchased from the local markets, cut into small pieces and dried in shadow. The powdered strawberry was then extracted with methanol using Soxhlet extraction techniques. Following evaporation, crude methanolic extracts were stored at room temperature under sterile conditions until further use.

\section{Maintenance of cell lines}

KB cell lines were procured from National Centre for Cell Sciences, Pune. The cells were maintained in Minimal Essential Medium enhanced with $10 \%$ FBS, streptomycin $(100 \mu \mathrm{g} / \mathrm{ml})$, and penicillin $(100 \mathrm{U} / \mathrm{ml})$ in a humidified atmosphere of $50 \mu \mathrm{g} / \mathrm{ml} \mathrm{CO}_{2}$ at $37^{\circ} \mathrm{C}$. The vial containing the KB cell lines acquired from ATCC (CCL-17) was removed from liquid nitrogen freezer and immediately placed in a $37^{\circ} \mathrm{C}$ water bath. It was agitated continuously until the medium thawed. Then, it was centrifuged for $10 \mathrm{~min}$ at $150-200 \times \mathrm{g}$ room temperature. Supernatant was discarded and cells were washed with fresh medium to remove residual dimethyl sulfoxide (Table 1 ).

(3-[4,5-Dimethylthiazol-2-yl]-2,5-diphenyltetrazolium bromide) (MTT) assay

MTT is a water-soluble tetrazolium salt, which on cleavage by succinate dehydrogenase is converted to an insoluble purple formazan by cleavage of the tetrazolium ring within the mitochondria. The formazan product thus formed is impermeable to the cell membranes, and therefore, it accumulates in healthy cells [16]. The KB cells were routinely grown and subcultured as monolayers in Dulbecco's Minimal Essential Medium supplemented with $10 \%$ newborn calf serum. The experiments in this 
Table 1: Cell viability assay of SBE-treated KB cell lines

\begin{tabular}{llll}
\hline S. No & Treatment & Concentration $(\mu \mathbf{g} / \mathbf{m l})$ & Absorbance 540 nm \\
\hline 1 & KB untreated cells & & 0.318 \\
2 & SBE treated & 25 & 0.267 \\
3 & & 50 & 0.221 \\
4 & & 100 & 0.205 \\
5 & Cyclophosphamide & 100 & 0.097 \\
\hline
\end{tabular}

Results are expressed as Mean \pm SEM $(n=3) .{ }^{*} \mathrm{p}<0.001$ statistically different in comparison with KB-untreated cells. SEM: Standard error of the mean, SBE: Strawberry methanolic extract

investigation were conducted with cells that had been initially batch cultured for 10 days. At this stage, the cells were harvested and plated at approximately 30,000 cells/well in 96-well microtiter plates and left to rest for $24 \mathrm{~h}$ at $37^{\circ} \mathrm{C}$ in a humidified atmosphere of $5 \% \mathrm{CO}_{2}$. The cells were then exposed to with/without various concentrations of the extract or the medium alone (as normal). Concentrations of the extract ranging of $25-100 \mu \mathrm{g} / \mathrm{ml}$ were used.

At the end of the period, cytotoxicity was assessed by estimating the viability of the KB cells by the MTT reduction assay. After $1 \mathrm{~h}$ incubation, the test solution from each well was removed by aspiration and replaced with $50 \mu \mathrm{l}$ of MTT prepared in minimum essential media (MEM) without phenol red (MEM). The plates were gently shaken and incubated for $3 \mathrm{~h}$ at $37^{\circ} \mathrm{C}$ in a humidified $5 \% \mathrm{CO}_{2}$ atmosphere. The supernatant was removed and $50 \mu \mathrm{l}$ of propanol was added and the plates were gently shaken to solubilize the formed formazan. The absorbance was measured using a microplate reader at $540 \mathrm{~nm}$.

In the cell viability, reduction of MTT can occur only in metabolically active cells, the level of cell activity is a measure of the viability of the cells. This is measured by absorbance of the spectrophotometer and the intensity is compared and the means were compared. The solution transferred to centrifuge tubes and that was centrifuged at top speed 2 min to precipitate cell is calculated by the following formula:

$$
\% \text { cell viability }=\frac{\text { Absorbance of test }}{\text { Absorbance of control }} \times 100
$$

\section{Cytotoxicity assay by neutral red (NR) incorporation}

The NR incorporation method, described by Borenfreund and Puerner (1985), was used to evaluate cytotoxicity through lysosome viability. Different concentrations of extracts were obtained by dissolution in maintenance medium (MM). They were tested in a range from 0 to $2.5 \mathrm{mg} / \mathrm{ml}$ of SBE. After exposure for $24 \mathrm{~h}$, the assay was performed according to Trintinaglia et al. (2015). Cell monolayers grown in were incubated for $24 \mathrm{~h}$ at $37^{\circ} \mathrm{C}$ with different concentrations of extracts, in triplicate. Then, medium was removed and $500 \mu \mathrm{L}$ of NR solution $(30 \mu \mathrm{g} / \mathrm{ml}$ in $\mathrm{MM})$ was added to each well. The plates were incubated once more for $3 \mathrm{~h}$ at $37^{\circ} \mathrm{C}$ to promote the uptake of the dye by cells. Subsequently, the supernatant was removed. The monolayers were washed with PBS, and $500 \mu \mathrm{L}$ of extraction solution $\left(\mathrm{H}_{2} \mathrm{O}\right.$ :acetic acid:ethanol) (49:1:50) was incorporated in each well. After gently shaking the plates, the absorbance was read on a spectrophotometer at $540 \mathrm{~nm}$. Monolayers incubated only with MM were used as control.

\section{RESULTS AND DISCUSSION}

On testing, the oral cancer cell lines with strawberry extract for any noticeable cytotoxic activity after incubation both the MTT assay and the NR incorporation tests did show effective results with low cell viability percentage on application of strawberry extract, thereby giving path to apoptosis-related activity on the cancerous oral mucosa layer. Cytotoxic activity may also be carried out using the 2,3-bis-(2-methoxy4-nitro-5-sulfophenyl)-2H-tetrazolium-5-carboxanilide, resulting in a water-soluble product, in other words, the MTS assay [17]. The conversion of cellular macromolecules to specific ROS during normal cellular metabolism is the causation for many chronic diseases which include cardiovascular diseases, arthritis, diabetes, and many types of cancer [18].

\section{NR incorporation}

Major causes of cellular injury in an increasing number of diseases including cancer are the ROS. ROS are created in the cell mostly through the normal cellular metabolism [19]. Environmental factors such as ultraviolet light and toxic chemicals, as well as the inflammatory process, result in their production. ROS produced by sources alternatively include carcinogens, by ionizing radiation and by phagocytic cells involved in the inflammatory response contributing to these diseases [20]. Antioxidants play a major role in the interception of ROS or limiting their cellular effects. Natural remedies such as treating cancer by analyzing the cytokines activity in vitro of sweet potato also have been of budding areas of research owing to its properties of antidiabetic, antimutagenicity, immunostimulatory, and memoryenhancing properties [21].

Berries exhibit high antioxidant potential, exceeding that of many other foodstuffs mainly due to their comprisal phenolic and flavonoid compounds. Berry constituents also influence cellular processes associated with cancer progression including signaling pathways associated with cell proliferation, differentiation, apoptosis, and angiogenesis [22]. Strawberry, Korean raspberry, and mulberry extracts are known to have anticancer effects on cervical and breast cancer cell lines [23] which support this present evidence for the anticancer action of SBE. Phenolic compounds of strawberry have been found to have effectively inhibited the growth of human oral (CAL-27 and KB), colon (HT29 and HCT-116), and prostate (LNCaP and DU145) cancer cells [24-26]. Moreover, also strawberry extracts inhibited the growth of human colon (HCT-116), lung (A549), stomach (SNU-638), and fibrosarcoma (HT-1080) cancer cells [27 29]. In addition, previous studies have reported that dietary freeze-dried strawberries and Korean raspberries have the ability to inhibit $\mathrm{N}$-nitrosomethylbenzylamine-induced tumorigenesis in the rat $[30,31]$. Therefore, all these strong evidences support the findings of the current study which proves that strawberry is a strong anticancer agent which induces apoptosis of KB cells, so the cell viability percentage decreases (Fig. 1).

\section{CONCLUSION}

Even though there exist many chemical drugs for the treatment of oral carcinoma, they have adverse side effects which make the patient feel he would have been dead rather than being walking dead person with immense side effects. Hence, there are alternative forms of drugs given by nature which has bioactive substance which acts against oral cell lines and has immense promising therapeutic uses which can be used to treat cancer patients in medical field.

\section{AUTHOR'S CONTRIBUTION}

Ramya G has performed the review of literature, biochemical analysis, and compilation of paper. Dr. Vishnu Priya V has majorly provided with the literature survey, research proposal, and paper writing. Gayathri R has performed statistical analysis and phytochemical work. 


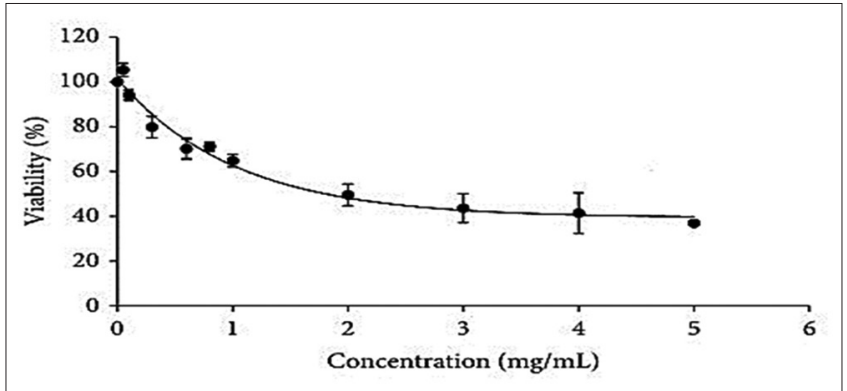

Fig. 1: Cell viability in strawberry methanolic extract-treated KB bells using neutral red incorporation. The results are expressed as mean \pm standard error of the mean $(n=3)$

\section{CONFLICTS OF INTEREST}

The authors declare that there are no conflicts of interest regarding the publication of this article.

\section{REFERENCES}

1. Packyanathan JS, Gayathri R, Vishnupriya V. Preliminary phytochemical analysis and cytotoxicity potential of Bacopa monnieri on oral cancer cell lines. Int J Pharm Sci Rev Res 2016;39:4-8.

2. Rahman M, Islam SN. Effect of serum antioxidants (vitamin E, C and A) in lung cancer patients. Int J Pharm Pharm Sci 2014;6:578-80.

3. Weisburger JH. Mechanisms of action of antioxidants as exemplified in vegetables, tomatoes and tea. Food Chem Toxicol 1999;37:943-8.

4. Fuchs-Tarlovsky V. Role of antioxidants in cancer therapy. Nutrition 2013;29:1521

5. Masters RW. Animal cell culture, cytotoxicity and viability assays. $3^{\text {rd }}$ ed. Oxford: Oxford University; 2000. p. 202-203.

6. Tau sigma SJ, Batkin S. Bromelain, the enzyme complex of pineapple (Ananas comosus) and its clinical application. An update. J Ethnopharmacol 1988;22:191-203.

7. Kresty LA, Morse MA, Morgan C, Carlton PS, Lu J, Gupta A, et al. Chemoprevention of esophageal tumorigenesis by dietary administration of lyophilized black raspberries. Cancer Res 2001;61:6112-9.

8. Eberhardt MV, Lee CY, Liu RH. Antioxidant activity of fresh apples. Nature 2000;405:903-4.

9. Sun J, Chu YF, Wu XZ, Liu RH. Antioxidant and anti proliferative activities of vegetables. J Agric Food Chem 2002;50:6910-16

10. Steinmetz KA, Potter JD. Vegetables, fruit and cancer. II mechanisms. Cancer Causes Control 1991;2:427-42.

11. Willett WC. Diet, nutrition, and avoidable cancer. Environ Health Perspect 1995; 103:165-70.

12. Block G. Fruit, vegetables and cancer prevention: A review ofthe epidemiological evidence. Nutr Cancer 1992;18:1-29.

13. Ames BN. Endogenous mutagens and the causes of aging and cancer. Mutat Res 1991;250:3-16.
14. World Cancer Research Fund/American Institute for Cancer Research. Food, Nutrition, Physical Activity, and the Prevention of Cancer: A Global Perspective. AICR, Washington, DC; 2007.

15. Wedge DE, Meepagala KM, Magee JB, Smith SH, Huang G, Larcom LL. Anticarcinogenic activity of strawberry, blueberry, and raspberry extracts to breast and cervical cancer cells. J Med Food 2004;4:49-51.

16. Fotakis G, Timbrell JA. In vitro cytotoxicity assays: Comparison of LDH, neutral red, MTT and protein assay in hepatoma cell lines following exposure to cadmium chloride. Toxicol Lett 2006;160:171-7.

17. Menon A, Vishnupriya V, Gayathri R. Preliminary phytochemical analysis and cytotoxicity potential of pineapple extract on oral cancer cell lines. Asian J Pharm Clin Res 2016;9:140-3.

18. Chen T, Rose ME, Hwang H, Nines RG, Stoner GD. Black raspberries inhibit N-nitroso methylbenzylamine (NMBA)-induced angiogenesis in rat esophagus parallel to the suppression of COX-2 and iNOS. Carcinogenesis 2006;27:2301-7.

19. Hong JY, Song SH, Park HJ, Cho YJ, Pyee JH, Lee SK. Antioxidant, ant inflammatory, and ant proliferative activities of strawberry extracts. Biomol Ther 2008; 16:286-92.

20. Carlton PS, Kresty LA, Siglin JC, Morse MA, Lu J, Morgan C, et al. Inhibition of N-nitro so methyl benzyl amine-induced tumorigenesis in the rat esophagus by dietary freeze-dried strawberries. Carcinogenesis 2001;22:441-6.

21. Prashanth NV, Dilip C, Dev KT, Augustine L, Saraswathi R. Research Article Evaluation of cytotoxic, in vitro antioxidant activities of Ipomea batatas. Int J Pharm Pharm Sci 2010;2:91-2.

22. Rao SJ, Ramesh CK, Mahmood R, Jamuna KS, Prabhakar BT. Antitumor activity of two species of mulberry against eat cell lines in mice. World J Pharm Res 2015;4:1934-43.

23. Zhang Y, Seeram NP, Lee R, Feng L, Heber D. Isolation and identification of strawberry phenolics with antioxidant and human cancer cell antiproliferative properties. J Agric Food Chem 2008;56:670-5.

24. Seeram NP, Lee R, Scheuller HS, Heber D. Identification of phenolic compounds in strawberries by liquid chromatography electrospray ionization mass spectroscopy. Food Chem 2006;97:1-11.

25. Xue H, Aziz RM, Sun N, Cassady JM, Kamendulis LM, Xu Y, et al. Inhibition of cellular transformation by berry extracts. Carcinogenesis 2001;22:351-6.

26. Arfan M, Khan R, Rybarczyk A, Amarowicz R. Antioxidant activity of mulberry fruit extracts. Int J Mol Sci 2012;13:2472-80.

27. Stoner GD, Wang LS, Casto BC. Laboratory and clinical studies of cancer chemoprevention by antioxidants in berries. Carcinogenesis 2008;29:1665-74.

28. Hasan S, Elongovan S. Conventional and advanced diagnostic aids in oral cancer screening-the journey so far. Int J Pharm Pharm Sci 2015;7:29-33

29. Umesh TG. In vitro antioxidant potential, free radical scavenging and cytotoxic activity of Simarouba gluaca leaves. Int J Pharm Pharmaceu Sci 2015;7:411-16.

30. Tsao R. Chemistry and biochemistry of dietary polyphenols. Nutrients 2010;2:1231-46.

31. Gug K. Physiological and whitening effects of Morus alba extracts. J Chosun Nat Sci 2012;5:46-52. 